Jurnal Instruksional, Volume 1, Nomor 2, April 2020 |

ISSN: 2686-5645

\title{
PENGEMBANGAN MODEL CASE CONFERENCE PADA ANAK BERKEBUTUHAN KHUSUS
}

\author{
Dindin Rosyidin ${ }^{1}$, Zulfitria ${ }^{2}$, Dirgantara Wicaksono ${ }^{3}$ \\ ${ }^{1}$ SD Lab School FIP UMJ Jl. K.H Ahmad Dahlan Ciputat Tangerang 15419 \\ email: dirosya@yahoo.co.id \\ ${ }^{2}$ Magister Teknologi Pendidikan, Universitas Muhammadiyah Jakarta \\ email: fzulfitria@umj.ac.id \\ ${ }^{3}$ Magister Teknologi Pendidikan, Universitas Muhammadiyah Jakarta \\ email: dirgantarawicaksono@umj.ac.id
}

\begin{abstract}
Each of children with special need in Labschool FIP UMJ is assisted by classroom teacher, assistant teacher, shadow teacher, and some therapists in his house. They have their own program and achievement so that it can cause overlapping among them. Thus it is necessary to develop and integrate a holistic model and integrated program to handle children with special needs. The study provides the development of Case Conference Model at children with special need. The study used research and development $(R \& D)$. The model used in the study is ADDIE model. It stands for analysis, design, develop, implement, and evaluate. The population in the study is special need's children at Labschool FIP UMJ. The output of the study is case conference model which can be used for children with special need. The implementation of Case Conference model can help teacher, shadow teacher, parents and principle in dealing with special need's children.
\end{abstract}

Keywords: case conference, children with special needs

\begin{abstract}
Abstrak
Setiap anak berkebutuhan khusus di SD Lab School FIP UMJ didampingi oleh guru kelas, guru pendamping, shadow teacher dan terapis di rumahnya. Mereka masing-masing memiliki program tersendiri dan capaian tersendiri sehingga tidak terjadi tumpang tindih antar program satu dengan program lainnya. Dengan demikian perlu adanya pengembangan model yang bersifat holistik dan mengintegrasikan program penanganan anak berkebutuhan khusus. Tujuan dari studi ini adalah untuk meneliti bagaimana mengembangkan model Case Conference pada Anak Berkebutuhan Khusus dengan model ADDIE dan memberikan pedoman tentang langkah-langkah dalam mengimplementasikan model case conference pada anak berkebutuhan khusus. Penelitian dilakukan dengan pendekatan Research and Development (R\&D). Model pengembangan yang digunakan adalah model ADDIE (analysis, design, develop, implement, evaluate). Populasi dalam penelitian ini adalah anak berkebutuhan khusus SD Lab School FIP UMJ. Output dari penelitian ini adalah model case conference yang dapat digunakan untuk anak berkebutuhan khusus. Penerapan model case conference dapat membantu guru kelas, shadow teacher, orang tua dan kepala sekolah dalam menangani anak berkebutuhan khusus.
\end{abstract}

Kata kunci: case conference, anak berkebutuhan khusus

\section{PENDAHULUAN}

Case conference bukan hal baru dalam istilah psikologi. Case conference adalah salah satu kegiatan pendukung bimbingan dan konseling untuk membahas suatu permasalahan pada petemuan yang dihadiri oleh pihak-pihak yang terkait dalam mendapatkan keterangan yang digunakan untuk mengentaskan suatu permasalahan dimana semua steak holder yaitu kepala sekolah, orang tua, guru kelas, shadow teacher, guru remedial dan terapis dapat 
Jurnal Instruksional, Volume 1, Nomor 2, April 2020 |

ISSN: $2686-5645$

memberikan kontribusi sesuai dengan tugas pokok dan fungsinya agar pimpinan case conference dapat membuat langkah-langkah yang menyeluruh untuk menangani anak berkubutuhan khusus. Di samping itu, sekolah belum memiliki panduan jelas yang isinya berupa standar operasional prosedur (SOP) dalam menangani siswa ABK sehingga dapat dijadikan acuan untuk guru kelas, guru pendamping, shadow teacher dan orang tua dalam menangani anak berkebutuhan khusus.

Penelitian dan pengembangan berfungsi untuk memvalidasi dan hanya menguji efektivitas atau validitas produk tersebut. Mengembangkan dan memvalidasi produk, berarti bahwa produk itu telah ada, dan peneliti produk dalam arti yang luas dapat berupa memperbarui produk yang telah ada (sehingga menjadi lebih praktis, efektif, dan efisien) atau menciptakan produk baru (yang sebelumnya belum pernah ada. (Sugiyono, 2017: 28).

Berdasarkan uraian para ahli di atas, maka dapat dipahami konsep pengembangan model merupakan cara ilmiah untuk meneliti, merancang, memproduksi dan digunakan untuk merancang prosedur dan produk baru, yang kemudian diujikan di lapangan secara sistematis, dievaluasi, dan disempurnakan sampai memenuhi kriteria efektivitas yang ditentukan, kualitas, atau standar yang sama.

Maribe Branch Robert (2009:2) mengembangkan desain pembelajaran dengan ADDIE yang merupakan kepanjangan dari analysis, design, development, implementation and evaluation. Analyze yaitu berhubungan dengan kegiatan analisis tentang situasi kerja dan lingkungan sehingga dapat dihasilkan suatu pemikiran atau gagasan tentang produk apa yang perlu dikembangkan. Design berkaitan dengan kegiatan merancang produk yang sesuai dengan need analysis (analisis kebutuhan). Develepment adalah kegiatan pembuatan dan pengujian produk. Implementation adalah kegiatan menggunakan produk di lapangan dan langkah terakhir adalah Evaluation yaitu melakukan penilaian terhadap langkah- langkah kegiatan dan penilaian terhadap produk yang telah dibuat apakah sudah sesuai dengan spesifikasi atau belum. Dari gambar $2.3 \mathrm{di}$ atas, peneliti memberikan kesimpulan bahwa langkah-langkah ADDIE merupakah sebuah siklus dimana jika dalam langkah akhir yakni evaluasi mengisyaratkan bahwa produk yang dihasilkan belum memenuhi spesifikasi yang telah ditentukan, maka peneliti harus kembali melakukan langkah awal yaitu kegiatan analisis. Dengan adanya siklus tersebut, produk yang dihasilkan akan efektif, efisien dan berkualitas.

Penelitian ini bertujuan untuk mengetahui bagaimana pengembangan model case conference pada Anak Berkebutuhan Khusus dengan model ADDIE dan memberikan penjelasan tentang langkah dalam mengimplementasikan model case conference pada anak berkebutuhan khusus. Penelitian dibatasi pada masalah sebagai berikut: 1. Model yang digunakan dalam penelitian ini dibatasi pada model Case Conference pada anak berkebutuhan khusus. 2. Anak berkebutuhan khusus pada penelitian ini adalah anak autis kelas rendah.

\section{KAJIAN LITERATUR \\ Case Conference}

Case conference adalah salah satu kegiatan pendukung bimbingan dan konseling untuk membahas suatu permasalahan dalam suatu petemuan yang dihadiri oleh pihakpihak yang terkait untuk mendapatkan keterangan yang digunakan untuk mengentaskan suatu permasalahan. Dengan adanya case conference dapat dihasilkan program penanganan yang bersifat integral artinya semua pihak memiliki langkahlangkah yang sama agar tercapainya tujuan yang diinginkan.

Prayitno (2004:334) menyatakan bahwa konferensi kasus itu untuk kepentingan: (1) diperolehnya gambaran yang lebih jelas, mendalam dan menyeluruh tentang permasalah siswa; gambaran yang diperoleh itu lengkap dengan saling sangkut paut data atau keterangan yang satu dengan yang lain, 
Jurnal Instruksional, Volume 1, Nomor 2, April 2020 |

ISSN: 2686-5645

(2) terkomunikasikannya sejumlah aspek permasalahan kepada pihak-pihak yang berkepentingan dan yang bersangkutan, sehingga penanganannya itu menjadi lebih mudah dan tuntas, dan (3) terkoordinasikannya penanganan masalah yang dimaksud sehingga upaya penanganan itu lebih efektif dan efisien.

Sukardi (2019: 293) menjelaskan bahwa tujuan konferensi kasus secara khusus antara lain: (1) untuk mendapatkan suatu konsesus dari para ahli dalam menafsirkan data atau informasi yang cukup memadai dan komprehensif tentang siswa atau kasus guna memudahkan pengambilan keputusan, (2) menetapkan cara yang terbaik untuk menangani kasus, (3) sebagai langkah awal dalam penetapan rujukan (referral) bila dibutuhkan bantuan di luar kemampuan dan tanggungjawab konselor dan, (4) adanya koordinasi dalam penanggulangan masalah oleh berbagai pihak yang berkepentingan.

Berdasarkan uraian di atas, maka dapat disimpulkan tujuan konferensi kasus untuk mengetahui permasalahan yang terjadi pada siswa, dan menciptakan metode atau cara penanganannya serta melibatkan pihak yang berkepentingan agar penanganan masalah bisa lebih efektif dan efisien. Prosedur case conference agar dapat berjalan dengan baik maka perlu dilakukan perencanaan, pelaksanaan, analisis dan evaluasi serta tindak lanjut.

\section{Anak Berkebutuhan Khusus}

Undang-Undang Republik Indonesia Nomor 20/2003 tentang Sistem Pendidikan Nasional bab IV pasal 5 ayat 2, 3, dan 4 dinyatakan bahwa anak berkebutuhan khusus adalah:

1. Anak yang memiliki kelainan fisik, emosional, mental, intelektual, dan atau sosial sehingga berhak memperoleh pendidikan khusus.

2. Anak di daerah terpencil atau terbelakang serta masyarakat adat yang terpencil sehingga berhak memperoleh pendidikan layanan khusus.
3. Anak yang memiliki potensi kecerdasan dan bakat istimewa sehingga berhak memperoleh pendidikan khusus.

Undang-undang di atas menjabarkan bahwa anak berkebutuhan khusus adalah:

1. Anak yang memiliki kelainan fisik, antara lain tunanetra, tunarungu, tunadaksa, tunawicara, dan tunaganda.

2. Anak dengan kelainan emosional dan atau mental; anak dengan gangguan pemusatan perhatian dan hiperaktif, autisme.

3. Anak dengan kelainan intelektual yaitu tunagrahita

4. Anak dengan kelainan sosial yaitu tunalaras.

5. Anak dengan potensi cerdas istimewa dan bakat istimewa.

6. Anak di daerah terpencil seperti anak rimba, suku badui dan lain-lain.

Dari penjelasan di atas penulis dapat menyimpulkan bahwa anak berkebutuhan khusus mempunyai karakteristik yang berbeda antara yang satu dengan yang lainnya. Karena karakteristik dan hambatan yang dimilki, ABK memerlukan bentuk pelayanan pendidikan khusus yang disesuaikan dengan kemampuan dan potensi mereka.

Prasetyono (2008:27) mengatakan bahwa autisme dikategorikan dalam gangguan perkembangan persuasif yaitu kelainan kualitatif dalam interaksi sosial yang timbal balik (reciprocal) dan dalam pola komunikasi serta minat dan aktivitas yang terbatas, stereotipik dan berulang. Autisme atau bisa disebut dengan ASD (Autistic Spectrum Disoder) merupakan suatu kumpulan sindrom yang mengganggu saraf yang mana diagnosisnya diketahui dari gejala yang tampak dan ditujukkan dengan adanya penyimpangan perkembangan.

Untuk mengetahui kebutuhan belajar anak autis seorang guru perlu atau wajib memahami ciri-ciri dari anak autis, anak autis memiliki karakteristik yang khas bila dibandingkan dengan anak berkebutuhan khusus lainnya. Secara umum anak autis memiliki karakteristik sebagai berikut: 
Jurnal Instruksional, Volume 1, Nomor 2, April 2020 |

ISSN: $2686-5645$

1. Tidak memiliki kontak mata/kontak mesra dengan orang lain atau lingkungannya, yang dimaksud kontak mata atau kontak mesra, anak autis umumnya tidak dapat melakukan kontak mata atau menutup pandangan guru, orangtua atau lawan bicaranya ketika melakukan komunikasi;

2. Selektif berlebihan terhadap rangsang, anak autis diantaranya sangat selektif terhadap rangsangan, seperti tidak suka dipeluk, merasa seperti sakit ketika dibelai guru atau orangtuanya. Beberapa anak ada yang sangat terganggu dengan warna-warna tertentu;

3. Respon stimulasi diri yang menganggu interaksi sosial. Anak autis seringkali melakukan atau menunjukkan sikap seperti mengepak-ngepakkan tangan, memukulmukul kepala. Menggigit jari tangan ketika merasa kesal atau merasa panik dengan situasi lingkungan yang baru dimasukinya;

4. Ketersendirian yang ekstrim. Anak autis umumnya senang bermain sendiri, hal ini karena anak tidak melakukan interaksi sosial dengan lingkungannya. Anak akan menjadi lebih parah bila mereka dibiarkan bermain sendiri;

5. Melakukan gerakan tubuh yang khas, seperti menggoyang-goyangkan tubuh, jalan berjinjit, menggerakkan jari ke tangan.

\section{METODE PENELITIAN}

Metode yang digunakan dalam penelitian ini adalah metode penelitian dan pengembangan (Research and Develovment). Pengembangan model yang digunakan dalam penelitian ini adalah Model Desain Pembelajaran ADDIE yang dipadukan menurut langkah-langkah penelitian pengembangan yang direkomendasikan oleh Robert Maribe Branch dengan dasar pertimbangan bahwa model tersebut cocok untuk mendesain produk model pembelajaran yang tepat sasaran, efektif dan dinamis dan sangat membantu dalam pengembangan model case conference pada anak berkebutuhan khusus untuk guru. Adapun langkah-langkah penelitian dan pengembangan yaitu penelitian pendahuluan; perencanaan pengembangan model, validasi, evaluasi dan revisi model; serta implementasi model.

\section{HASIL DAN PEMBAHASAN}

Berdasarkan kajian teoretik tentang pengembangan model case conference pada anak berkebutuhan khusus dengan menggunakan model ADDIE dapat dikemukakan kerangka pengembangan model Case Conference pada anak berkebutuhan khusus.

\section{Analysis (Analisis)}

Pada tahun ajaran 2018-2019 SD Lab School FIP UMJ menerima siswa yang terindikasi anak berkebutuhan khusus berdasarkan hasil observasi yang dilakukan oleh Deden Mulyadi, M.Psi dengan SIPP: 1544-14-2-. Standar observasi mengacu kepada kerangka penilaian yang ditetapkan oleh psikolog. Pada proses penerimaan peserta didik baru, untuk mengetahui kesiapan belajar calon siswa yang akan belajar di SD Lab School FIP UMJ, panitia penerimaan peserta didik baru SD Lab School FIP UMJ telah membuat jadwal observasi. Observasi bersifat klasikal dimana satu kelas terdiri dari 10 sampai dengan 15 siswa dan didampingi oleh 1 guru kelas dan 1 guru pendamping.

Psikolog yang ditugaskan untuk mengobservasi berjumlah 1 orang. Kegiatan observasi berlangsung selama 1 jam. Aspekaspek yang diobservasi oleh psikolog yaitu daya tahan, persepsi visual, koordinasi visual motorik, kemampuan bahasa, konsentrasi, kemandirian, penyesuaian diri, kematangan emosi, daya tahan, dan minat belajar. Output dari observasi ini adalah berupa rekomendasi psikolog yang terdiri dari kategori disarankan dipertimbangkan, dan tidak disarankan. Bagi siswa yang berkebutuhan khusus meskipun hasil rekomendasi psikolog disarankan, dia akan diterima oleh sekolah bilamana quota siswa berkebutuhan khusus masih tersedia. Adapun quota siswa berkebutuhan khusus 
Jurnal Instruksional, Volume 1, Nomor 2, April 2020 |

ISSN: 2686-5645

dari setiap kelas berjumlah 1 siswa. Tahun ajaran 2018-2019 SD Lab School FIP UMJ menerima 4 kelas, sehingga quota siswa yang berkebutuhan khusus berjumlah 4 siswa.

Dari hasil observasi langsung yang dilakukan oleh peneliti, terdapat beberapa kebutuhan yang urgen untuk anak berkebutuhan khusus antara lain:

1. Perlunya proses pembelajaran yang aktif dan menyenangkan

2. Media pembelajaran yang digunakan guru dalam peroses pembelajaran sebaiknya menggunakan benda-benda konkret.

3. Perhatian guru dalam melibatkan anakanak ABK pada semua aktifitas pembelajaran dan interaksi sosial sangat diperlukan.

4. Koordinasi antara guru kelas, shadow teacher, guru mata pelaran, kepala sekolah, orang tua harus terjalin dengan baik.

5. Latihan-latihan yang terstruktur baik dalam kegiatan pembelajaran maupun dalam kegiatan interakasi sosial harus sering dilakukan.

Dari kebutuhan analisis di atas, peneliti memberikan model pengembangan yang mampu mengintegrasikan intervensi atau perlakuan dari guru kelas, guru shadow teacher, orang tua dan kepala sekolah.

\section{Desain (rancangan model)}

Dari hasil-hasil analisis kebutuhan maka diperlukan suatu model yang dapat mengintegrasikan penanganan siswa ABK yang dilakukan oleh pihak-pihak yang berhubungan langsung maupun tidak langsung dengan siswa ABK. Model yang dirancang adalah model Case Conference. Model ini adalah model yang biasa digunakan oleh psikolog dalam menangani anak-anak yang bermasalah. Adapun rancangan model yang dibuat seperti terlihat pada gambar 4.1 di bawah ini:
Gambar 4.1

Model Case Conference

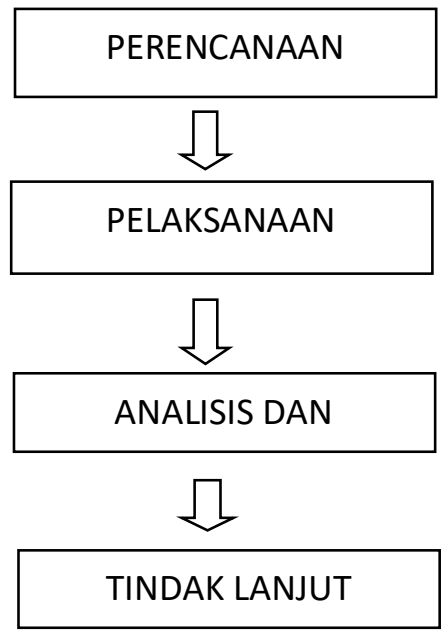

Gambar di atas adalah disain awal untuk melakukan case conference yang akan diterapkan pada siswa ABK.

\section{Develop (pengembangan)}

Pada tahap pengembangan ini peneliti telah mengembangkan model case conference yang sudah dirancang menjadi model praktis yang dapat diimplementasikan di sekolah untuk menangani siswa ABK kelas rendah. Adapun pengembangan model yang sudah dibuat adalah sebagai berikut:

\section{Perencanaan}

Dalam tahap perencanaan, terdapat komponen-komponen yang harus dipenuhi oleh pemimpin case conference.

a. Menentukan tujuan

Tujuan adalah hal penting sebelum melakukan case conference. Kepala sekolah sebagai pemimpin case conference harus merumuskan tujuan yang ingin dicapai dari pelaksanaan case conference.

b. Menentukan pihak siapa saja yang harus dihadirkan. Pihak yang terkait langsung dengan siswa $\mathrm{ABK}$ harus ditentukan oleh pemimpin case conference. Hal tersebut diperlukan agar pemimpin case conference mendapatkan gambaran yang utuh terhadap kondisi dan karakteristik siswa ABK yang akan menjadi obyek case conference. Widada (2017, 294) mengatakan beberapa pihak yang mutlak 
Jurnal Instruksional, Volume 1, Nomor 2, April 2020 |

ISSN: 2686-5645

dihadirkan ialah: kepala sekolah, guru bimbingan konseling, wali kelas, guru mata pelajaran, orangtua siswa, dan pihak lain seperti dokter, psikiater, psikolog maupun pembantu lain yang sekiranya kemampuan dan kewenangannya relevan dengan masalah yang sedang dibahas.

c. Menentukan waktu dan tempat pelaksanaan. Pemimpin case conference harus menentukan waktu dan tempat pelaksanaan dengan jelas. Waktu case conference tidak bisa dilaksanakan dalam satu hari selesei. Karena itu pemimpin case conference harus membuat time schedule atau urutan kegiatan secara spesifik. Time schedule paling tidak memuat sasaran dari sesi case conference, kegiatan, instansi atau profesi yang terlibat. Di samping waktu pelaksanaan, tempat pelaksanaan case conference harus ditentukan dengan jelas. Tempat pelaksanaan sebaiknya terhindar dari gangguan kenyamanan dan kebisingan agar peserta case conference dapat melakukan case conference dengan penuh konsentrasi.

d. Distribusi undangan. Pemimpin case conference melayangkan surat undangan kepada pihak-pihak yang akan ikut case conference.

e. Menyiapkan draft perencanaan. Pemimpin case conference sebelum melakukan kegiatan, membuat draft perencanaan halhal apa saja yang akan menjadi kajian ketika case conference dilaksanakan.

f. Mencari input dari semua peserta. Input awal maksudnya adalah dokumendokumen yang dapat dijadikan sebagai rujukan dari masing-masing peserta seperti dokumen kurikulum, program masing-masing pihak, atau catatan mengenai keadaan siswa ABK saat ini.

g. Mengirimkan rencana akhir. Rencana akhir dari masing-masing peserta agar dikrimkan kepada pemimpin case conference untuk diinventarisir sebagai kajian awal.

\section{Pelaksanaan}

Dalam tahap pelaksanaan, terdapat langkahlangkah yang harus dilakukan yaitu:

a. Elaborasi dan evaluasi. Pada sesi pertama case conference, Profesi dalam hal ini adalah mereka yang terkait langsung dengan siswa ABK yaitu guru kelas, shadow teacher, terapis, kepala sekolah dan orang tua. Masing-masing dalam tempat terpisah memberikan pemaparan tentang kondisi siswa ABK dari sudut pandang yang berbeda.

b. Mengidentifikasi pemecahan masalah Pada sesi kedua case conference masing-masing profesi mengidentifikasi pemecahan masalah dari sudut pandang masingmasing.

c. Membuat program bersama. Pada sesi ketiga (sesi akhir) case conference Dalam membuat program bersama, setiap profesi baik guru, shadow teacher, terapis, kepala sekolah menyamakan persepsi tentang program masing-masing untuk tujuan bersama yaitu untuk meningkatkan kemampuan siswa ABK.

d. Memberikan persetujuan dipimpin oleh seorang pemimpin case conference, masing-masing harus memberikan persetujuan terhadap program bersama yang telah dibuat.

\section{Tindak Lanjut}

a. Menuliskan kesimpulan. Pemimpin case conference menuliskan kesimpulankesimpulan berupa catatan masalahmasalah siswa ABK, program-program bersama dan memahami tugas pokok dan fungsi masing-masing.

b. Mendistribusikan kepada seluruh peserta. Program-program bersama yang telah disepakati kemudian didistribusikan kepada seluruh peserta untuk ditindak lanjuti dan dilaksanakan sesuai dengan bidangnya.

c. Mengevaluasi hasil. Pemimpin case conference harus mengevaluasi hasil yang ditunjukan oleh siswa melalui lembar observasi dan lembar pengamatan, untuk mengukur sejauh mana case conference 
Jurnal Instruksional, Volume 1, Nomor2, April 2020 |

ISSN: $2686-5645$

berdampak pada tumbuh kembang siswa ABK.

d. Membuat catatan tindak lanjut. Catatan tersebut sangat penting untuk mengetahui kendala dan hambatan yang ditemui oleh masing-masing peserta case coneference dan dapat dijadikan sebagai dasar untuk kembali mengadakan kegiatan case conference berikutnya tergantung pada asas kebutuhan dilaksanakannya case conference.

\section{Implementation (implementasi model)}

Implementasi model case conference telah diujicobakan kepada salah satu siswa ABK kelas 1 yang bernama Herjuno. Langkah pertama dalam melaksanakan case conference adalah dengan melakukan perencanaan. Dalam perencanaan ini kepala sekolah sebagai pemimpin case conference mengundang orang tua Juno untuk melakukan pembicaraan terhadap perkembangan Herjuno. setelah melakukan identifikasi masalah bersama orang tua Herjuno, pemimpin case conference memberikan rekomendasi agar orang tua dan sekolah bersepakat untuk melakukan kegiatan case conference dalam menangani siswa tersebut. Setelah case conference pertama dilakukan kemudian diadakan lagi case conference ke dua. Pada case conference ke dua ini adalah pembuatan program bersama-sama. Case conference kedua dilaksanakan pada Sabtu, 16 Februari 2019.

Berikut program masing-masing pihak yaitu guru kelas, shadow teacher dan orang tua.

\section{Guru Kelas}

a. Memperjelas pelaksanaan kurikulum 2013 pada tim dan kegiatan yang akan dilakukan di kelas dan kegiatan sekolah secara keseluruhan

b. Membuat program individual yang diterapkan khusus untuk Juno. Memberikan peran yang lebih kepada Juno di kelas agar terjadi interaksi antara guru dan Juno juga antara Juno dan Temannya, seperti memberikan kesempatan kepada
Juno untuk menghapus papan tulis, memimpin doa memulai pelajaran, dan meminta Juno untuk tampil di depan kelas.

\section{Shadow Teacher}

a. Memperjelas perencanaan program toilet training.

b. Memberikan dorongan agar bertanya kepada guru

c. Mengkoordinasikan RPP dengan guru kelas terkait hal-hal yang akan diajarkan.

d. Menjembatani kerjasama antara guru kelas dan orang tua

\section{Orang Tua}

a. Melakukan koordinasi dengan guru kelas terhadap materi pelajaran yang akan diajarkan di kelas

b. Membantu Juno dalam hal toilet training

c. Ikut mengajarkan Juno tentang cara makan yang efektif sehingga tidak ketinggalan dari temannya.

d. Memantau perkembangan Juno di kelas dengan cara menanyakan langsung hal-hal apa yang Juno lakukan di kelas di hari itu. Program bersama di atas lalu disetujui oleh semua pihak dan dilaksanakan dengan penuh komitmen dan tanggung jawab.

\section{Evaluation (evaluasi)}

Tahap berikutnya dari model ADDIE adalah evaluasi. Evaluasi dilakukan untuk mengetahui kendala-kendala yang dihadapi dalam setiap tahapan. Pada tahap evaluasi penulis memberikan lembar Questionnaire kepada semua pihak yang terlibat dalam kegiatan Case Conference. Dari jawaban yang diberikan oleh pihak-pihak yang terlibat dalam case conference dalam hal ini guru kelas, shadow teacher dan orang tua, didapatkan kesimpulan sebagai berikut:

1. Case conference sangat berguna bagi semua pihak untuk mencari titik temu dan kesesuaian program antara pihak sekolah dalam hal ini guru kelas, shadow teacher dan orang tua dalam menangani anak berkebutuhan khusus.

2. Kepala sekolah selaku pimpinan case conference telah mengatur jalannya kegiatan case conference dengan baik, 
Jurnal Instruksional, Volume 1, Nomor 2, April 2020 |

ISSN: $2686-5645$

sehingga tujuan dari case conference dapat tercapai.

3. Output dari case conference adalah tersusunnya program pembelajaran individual yang dibuat oleh semua pihak baik guru kelas, shadow teacher dan sekolah.

4. Saran yang didapatkan dari pihak orang tua yaitu sekolah sebagai penyelenggara case conference agar memastikan bahwa program pembelajaran individual yang telah dibuat dapat dilaksanakan dengan baik.

\section{KESIMPULAN}

Berdasarkan hasil analisis dan uji statistik pada pembahasan sebelumnya, maka dapat ditarik kesimpulan. Berdasarkan data yang diperoleh bahwa penerapan model case conference dapat membantu guru kelas, shadow teacher, terapis dan kepala sekolah dalam menangani anak berkebutuhan khusus. Untuk guru kelas case conference ini akan menjadi input terhadap perlakuan anak di kelas. Untuk shadow teacher masukan dari orang tua dan guru kelas akan memberikan penguatan terhadap apa-apa yang akan ditekankan kepada anak ABK. Untuk kepala sekolah, case conference akan menjadi alternatif sekolah untuk melakukan akselerasi dalam menangani siswa ABK.

Dalam menyebarluaskan model case conference pada anak berkebutuhan khusus ke sasaran yang lebih luas, maka peneliti memberikan saran antara lain: sebelum disebarluaskan model case conference pada anak berkebutuhan khusus ini perlu disusun serta diperhatikan kembali berdasarkan tujuan dan sasaran yang akan dicapai dan agar model case conference pada anak berkebutuhan khusus dapat digunakan oleh guru, terapis, maupun orang tua dalam menangani anak berkebutuhan khusus, maka sebaiknya dicetak lebih banyak lagi, sehingga dapat digunakan di sekolah maupun klinik yang membutuhkan.

Dalam mengembangkan penelitian ini ke arah lebih lanjut, peneliti mempunyai beberapa saran sebagai berikut: dalam penelitian ini sebaiknya dilakukan pada subyek yang lebih luas baik dari subjek itu sendiri, sekolah, atau yayasan lainnya yang dapat digunakan sebagai kelompok uji dan hasil penelitian model pengembangan case conference pada anak berkebutuhan khusus ini dapat disebarluaskan ke sekolah-sekolah baik negeri maupun swasta, klinis terapi, yayasan yang menangani anak berkebutuhan khusus.

\section{REFERENSI}

Branch, Robert Maribe. 2009. Instructional Design: The ADDIE Approach.

Handojo. 2008. Autisma, Jakarta: PT. Bhuana Ilmu Populer

Prasetyono, D.S. 2008. Serba-serbi Anak Autis. Jogjakarta: Diva Press

Sukardi, D. K. 2010. Pengantar Pelaksanaan Program Bimbingan dan Konseling di Sekolah, Jakarta: Rineka Cipta.

Sugiyono. 2013. Metode Penelitian \& Pengembangan, Bandung: Penerbit Alfabeta

Sugiyono. 2016. Metode Penelitian: Kuantitatif, Kualitatif, dan R\&D. Bandung: Alfabeta CV

Widada. 2017. Konferensi Kasus Sebagai Teknik Pemecahan Masalah Konsel, Proceeding seminar $4-6$ agustus 2017, Malang, Jawa Timur, Indonesia 